Research Article

\title{
Evaluation of hepatoprotective activity of the ethanolic extract of leaves of Mimosa pudica linn in carbon tetrachloride induced hepatic injury in albino rats
}

\author{
Ayan Purkayastha*, Pinaki Chakravarty, Babul Dewan
}

Department of Pharmacology, Silchar Medical College and Hospital, Silchar, Assam, India

Received: 03 February 2016 Accepted: 02 March 2016

*Correspondence to:

Dr. Ayan Purkayastha, Email: ayanp007@gmail.com

Copyright: () the author(s), publisher and licensee Medip Academy. This is an openaccess article distributed under the terms of the Creative Commons Attribution NonCommercial License, which permits unrestricted noncommercial use, distribution, and reproduction in any medium, provided the original work is properly cited.

\begin{abstract}
Background: The Mimosa pudica, invites attention of the researchers all over the world for its different pharmacological activities such as anti-diabetic, antitoxin, antioxidant and wound healing activities. In the present study we investigated the hepatoprotective effects of ethanolic extract of leaves of Mimosa pudica linn against carbon tetrachloride $(\mathrm{CCl} 4)$ induced hepatic injury in albino rats.

Methods: Liver damage in rats treated with $\mathrm{CCl} 4(1 \mathrm{ml} / \mathrm{kg} / \mathrm{bw})$, administered subcutaneously, on alternate days for one week) was studied by assessing parameters such as serum glutamate oxaloacetate transaminase (SGOT), serum glutamate pyruvate transaminase (SGPT), alkaline phosphatase (ALP) and bilirubin (total and direct). Silymarin $(100 \mathrm{mg} / \mathrm{kg}$ ) was used as the standard drug. The effects of ethanolic extract of Mimosa pudica $(400 \mathrm{mg} / \mathrm{kg}$ ) was observed on the following parameters. One group was given both ethanolic extract of Mimosa pudica and Silymarin to observe if there was any additive effect. In addition to biochemical parameters liver weight and histological sections were also studied. The statistical analysis of data was done by using one way ANOVA followed by Dunnet's t test.
\end{abstract}

Results: Administration of ethanolic extract of Mimosa pudica significantly prevented carbon tetrachloride induced elevation of serum SGOT, SGPT, ALP and bilirubin (total and direct) level. Histological examination of the liver section revealed improved hepatic architecture, after administration of Mimosa pudica. The results were comparable to that of Silymarin. No additive effect was observed.

Conclusions: Our study demonstrates hepatoprotective effect of Mimosa pudica in carbon tetrachloride induced liver injury.

Keywords: Mimosa pudica, Ethanolic extract, Hepatoprotective, Carbon tetrachloride, Albino rats.

\section{INTRODUCTION}

The liver is one of the major and largest organ of the body. It plays an important role in metabolizing carbohydrates, proteins, lipids and it also stores vitamins. ${ }^{1}$ It is involved in almost all the biochemical pathways of growth, defense against disease, nutrient supply, energy provision and reproduction. ${ }^{2}$ The liver is at a high risk of getting diseased by various foreign compounds because all these foreign compounds are eliminated by the liver. ${ }^{3,4}$ Plant materials are widely used to treat liver diseases and are often investigated for their protective and regenerative action on the damaged liver. ${ }^{5}$ Herbal medicine is based on the principle that plants contain some natural substances that can promote health and cure illness. ${ }^{6}$ The most important of these biologically active constituents of plants are alkaloids, flavonoids, tannins and phenolic compounds. ${ }^{3}$

Ingested alcohol produces striking metabolic imbalance in the liver and leads to the formation of reactive oxygen species and free radicals. The free radical leads to alteration induced in lipid peroxidation and several enzymatic and non-enzymatic reactions. Antioxidants prevent the free radical formation or interrupt an oxidizing chain reaction to minimize the damage caused by free radicals. Medicinal plants are considered to be an important source of antioxidant compounds and the 
therapeutic benefit of many medicinal plants is to their antioxidant properties. $^{7}$

Mimosa pudica also known as Chuimui or Lajwanti in hindi has been used in traditional medicine for its woundhealing, antimicrobial, analgesic and antiinflammatory, anticonvulsant, antidiarrhoeal, antioxidant, hypolipidemic, antiulcer activities. ${ }^{8-15} M$. pudica leaf extract showed the presence of bioactive components such as terpenoids, flavonoids, glycosides, alkaloids, phenols, tannins, saponins, and coumarins. ${ }^{16}$

The present study was performed to assess the hepatoprotective activity in rats against carbon tetrachloride induced hepatic injury to prove its claim in folklore practice against liver disorder.

\section{METHODS}

\section{Preparation of extract ${ }^{17}$}

Mimosa pudica Linn leaves were collected from a field near Basic Science Building, Silchar Medical College and Hospital. The plant sample was verified by Mrs. Purnima Dutta Choudhury, M. Sc., Associate Professor, Department of Botany, Cachar College, Silchar.

Absolute alcohol $(99.9 \% \mathrm{v} / \mathrm{v})$ was used for the extraction process as almost all the components of Mimosa pudica is soluble in ethanol solvent. The leaves were shade dried and powdered. The powder was subjected to extraction with absolute alcohol in Soxhlet Apparatus at $45^{\circ} \mathrm{C}$ for a period of 4 hours. The extract was collected and filtered using Whatman No 1 filter paper and the filtrate was then subjected to evaporation under reduced pressure until a soft semi solid mass was obtained. The sample was stored in the refrigerator as a stock solution dissolved in liquid paraffin in 1:2 ratio (sample: liquid paraffin) in an airtight container at a temperature of below $10^{\circ} \mathrm{C}$.

\section{Preliminary phytochemical analysis}

The ethanolic extract was then subjected to preliminary phytochemical analysis to assess the presence of various phytoconstituents, it revealed the presence of flavonoids, alkaloids and glycosides.

\section{Experimental animals}

Wistar albino rats of either sex weighing between 150200 grams were procured from M/s Chakraborty Enterprise, Kolkata. The animals were acclimatized under laboratory conditions.

The animals were housed under standard conditions of temperature $\left(25 \pm 2^{\circ} \mathrm{C}\right)$ and relative humidity $(30 \%-70 \%)$ with a 12:12 light-dark cycle. They were fed with standard laboratory food. Water was allowed ad libitum under strict hygienic conditions.

\section{Experimental induction of hepatotoxicity}

Liver toxicity was induced in rats by administrating carbon tetrachloride (CCl4) subcutaneously (sc), in a suspension of liquid paraffin (LP; $1: 2 \mathrm{v} / \mathrm{v}$ ) at a dose of 1 $\mathrm{ml} / \mathrm{kg}$ body weight, on alternate days, for one week. ${ }^{18}$

\section{Experimental methodology ${ }^{18}$}

In the experimental design the albino rats were assigned into five groups of six animals each. Group A was maintained as control which received liquid paraffin $(3 \mathrm{ml} / \mathrm{kg})$ only by subcutaneous route on alternate days for one week. Group B was maintained as induced group which received $\mathrm{CCl} 4$ subcutaneously in a suspension of liquid paraffin in $1: 2 \mathrm{v} / \mathrm{v}$ at the dose of $1 \mathrm{ml}$ of CCl4/ $\mathrm{kg}$ body weight on alternate days for one week. Group $\mathrm{C}$ served as standard and received Silymarin $(100 \mathrm{mg} / \mathrm{kg}$, p.o) daily and CCl4 (1ml/kg, s.c in a suspension of liquid paraffin in a ratio $1: 2 \mathrm{v} / \mathrm{v}$ ) on alternate days for one week. Group D served as test group and received ethanolic extract of the leaves of Mimosa pudica (400mg/kg, p.o) daily and $\mathrm{CCl} 4(1 \mathrm{ml} / \mathrm{kg}$, s.c in a suspension of liquid paraffin in a ratio $1: 2 \mathrm{v} / \mathrm{v}$ ) on alternate days for one week. Group E received ethanolic extract of the leaves of Mimosa pudica (400mg/kg, p.o) and Silymarin (100 $\mathrm{mg} / \mathrm{kg}$, p.o) daily and $\mathrm{CCl} 4(1 \mathrm{ml} / \mathrm{kg}$, s.c in a suspension of liquid paraffin in a ratio $1: 2 \mathrm{v} / \mathrm{v}$ ) on alternate days for one week.

On the eighth day blood was withdrawn by retro orbital puncture and serum separated by centrifugation for estimation of biochemical parameters like Total (TBL) and Direct Bilirubin (DBL), Alkaline Phosphatase (ALP), Serum glutamate oxaloacetate transaminase (SGOT), Serum glutamate pyruvate transaminase (SGPT).

\section{Histology}

The animals were sacrificed under mild ether anaesthesia and the liver was removed from each animal after dissection. The liver tissue was excised from the animals, washed with the normal saline to remove blood, fixed in $10 \%$ buffered neutral formalin for 12 hours and processed for paraffin embedding. Sections of $5 \mu \mathrm{m}$ thickness were cut using a rotary microtome. The sections were processed and passed through graded alcohol series, stained with alum haematoxylin and eosin, cleared in xylene and cover slipped in DPX. Histological examination was done under microscope. ${ }^{19}$

\section{Statistical analysis of data}

The statistical analysis of data was done by using one way ANOVA followed by Dunnet's t test. Values were expressed as Mean \pm SD $(n=6)$. The tests were considered to be significant when $\mathrm{p}<0.05$ and highly significant when $\mathrm{p}<0.01$. 


\section{RESULTS}

\section{Acute toxicity studies}

Ethanolic extract of Mimosa pudica did not produce any toxic symptoms or mortality upto the dose level of 2000 $\mathrm{mg} / \mathrm{kg}$ body weight in rats, and hence the extract was considered to be safe and non-toxic for further pharmacological screening.

\section{Hepatoprotective activity}

The results of Carbontetrachloride induced hepatotoxicity are shown in Table 1 . In the Carbon tetrachloride treated group, the significant acute hepato cellular damage is indicated by the elevated levels of SGPT, SGOT, ALP, TBL \& DBL. But the group which received the test drug of ethanolic extract at the dose of $400 \mathrm{mg} / \mathrm{kg}$ body weight p.o showed a significant decrease in the elevated levels of SGPT, SGOT, ALP,TBL and DBL and these biochemical parameters are comparable with the standard hepatoprotective drug Silymarin. Therefore, the silymarin and the ethanolic extract restored the altered level of enzymes significantly $(\mathrm{P}<0.01)$.

Table 1: Comparison of effects of different treatment groups on biochemical parameters in carbon tetrachloride induced hepatic injury in albino rats.

\begin{tabular}{|c|c|c|c|c|c|}
\hline \multirow[b]{2}{*}{ Groups } & \multicolumn{5}{|c|}{ Biochemical Parameters (Mean \pm SD) } \\
\hline & $\begin{array}{l}\text { Total Bilirubin } \\
(\mathrm{mg} / \mathrm{dl})\end{array}$ & $\begin{array}{l}\text { Direct Bilirubin } \\
(\mathrm{mg} / \mathrm{dl})\end{array}$ & SGOT(IU/L) & SGPT (IU/L) & ALP (IU/L) \\
\hline $\begin{array}{l}\text { Group A } \\
\text { (Control) }\end{array}$ & $0.788 \pm 0.095$ & $0.512 \pm 0.098$ & $64.05 \pm 9.583$ & $33.433 \pm 7.892$ & $115.333 \pm 12.758$ \\
\hline $\begin{array}{l}\text { Group B } \\
\text { (Induced) }\end{array}$ & $4.24 \pm 1.686^{*}$ & $2.048 \pm 1.181^{*}$ & $221.933 \pm 25.501 *$ & $221.3 \pm 33.825^{*}$ & $234.15 \pm 17.068^{*}$ \\
\hline $\begin{array}{l}\text { Group C } \\
\text { (Standard) }\end{array}$ & $1.015 \pm 0.165^{* *}$ & $0.663 \pm 0.103 * *$ & $84.943 \pm 15.349 * *$ & $74.783 \pm 19.181 * *$ & $111.0367 \pm 8.585 * *$ \\
\hline $\begin{array}{l}\text { Group D } \\
\text { (Test Drug) }\end{array}$ & $1.131 \pm 0.213^{* *}$ & $0.74 \pm 0.097 * *$ & $105.5 \pm 8.551 * *$ & $93.283 \pm 12.574 * *$ & $121.293 \pm 7.810^{* *}$ \\
\hline $\begin{array}{l}\text { Group E } \\
\text { (Test Drug + } \\
\text { Standard) }\end{array}$ & $0.985 \pm 0.143 * *$ & $0.6 \pm 0.067 * *$ & $90.237 \pm 11.423 * *$ & $79.267 \pm 7.169 * *$ & $106.455 \pm 12.700 * *$ \\
\hline
\end{tabular}

Values are mean \pm SD $(n=6)$, data were analysed using one way ANOVA and Dunnet's t test. Where, ** represents highly significant at $\mathrm{p}<0.01$ (Comparison of treatment groups C, D, E with induced group B) and * represents highly significant at $\mathrm{p}<0.01$ (Comparison of induced group B with control group A).

Table 2: Comparison of effects of different treatment groups on the weight of liver.

\begin{tabular}{|ll|}
\hline Groups & $\begin{array}{l}\text { Weight of liver } \\
\text { (gram) }\end{array}$ \\
\hline Group A (Control) & $4.262 \pm 0.380$ \\
\hline Group B (Induced) & $5.035 \pm 0.285 \# \#$ \\
\hline Group C (Standard) & $4.415 \pm 0.312^{*}$ \\
\hline Group D (Test drug) & $4.518 \pm 0.392^{*}$ \\
\hline Group E (Test drug + Standard) & $4.38 \pm 0.310^{* *}$ \\
\hline
\end{tabular}

Values are mean \pm SD $(n=6)$, data were analysed using one way ANOVA and Dunnet's t test, Where, \#\# represents highly significant at $\mathrm{p}<0.01$ (Comparison of Group B with Group A). Also, * represents significant at $p<0.05$ (Comparison of Group C and Group D with Group B) and ** represents highly significant at $p<0.01$ (Comparison of Group E with Group B).

\section{Effects of different treatment groups on weight of liver}

In the induced group i.e. Group B there is an increase in the weight of liver as compared to control group i.e Group A. The group which received Silymarin $(100 \mathrm{mg} / \mathrm{kg})$ i.e. Group C, the group that received ethanolic extract of the leaves of Mimosa pudica $(400 \mathrm{mg} / \mathrm{kg})$ i.e. Group D and the group which received both ethanolic extract of leaves of Mimosa pudica and Silymarin i.e. Group E showed no significant change in the weight of liver as compared to control group but significant change was demonstrated on comparison with induced group.

\section{Histological findings}

Histopathological liver sections of control group showed normal cellular architecture with distinct hepatic cells, sinusoidal spaces, and central vein (Figure 1a). Disarrangement of normal hepatic cells with necrosis and vacuolization are observed in Carbon tetrachloride intoxicated liver (Figure 1b). The liver sections of the rat treated with $400 \mathrm{mg} / \mathrm{kg}$ body weight p.o of ethanolic extract of Mimosa pudica followed by Carbontetrachloride intoxication (Figure 1c) showed less vacuole formation and absence of necrosis and overall less visible changes observed were comparable with standard Silymarin (Figure 1d), supplementing the protective effect of the test drug and the standard 
hepatoprotective drug. The group that received both Mimosa pudica extract and Silymarin showed similar features (Figure 1e).

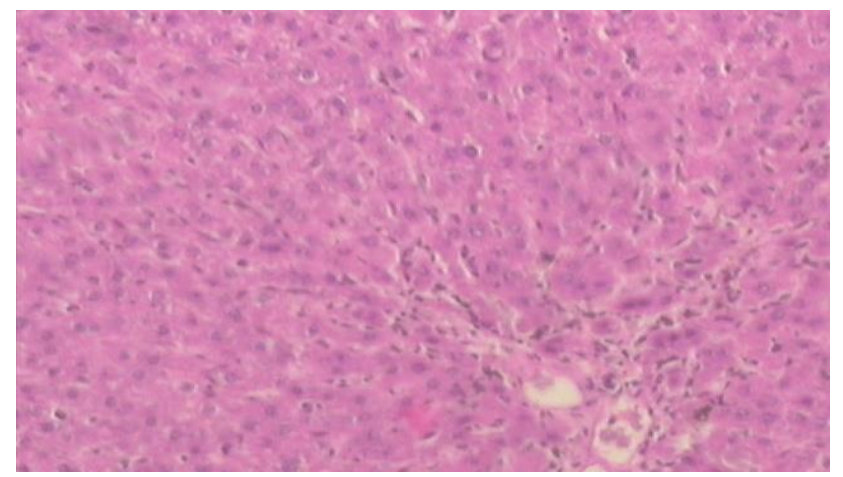

Figure 1a: Photomicrograph of liver from Group A showing normal hepatocellular architecture; H \& E stain. View: 10 x 40X.

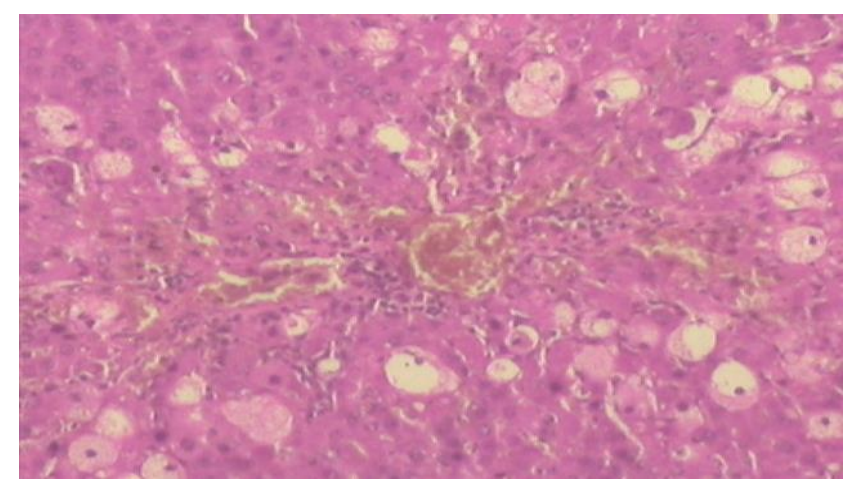

Figure 1b: Photomicrograph of liver from Group B showing features of hepatic injury $\mathrm{H} \& \mathrm{E}$ stain. View: $10 \times 40 X$.

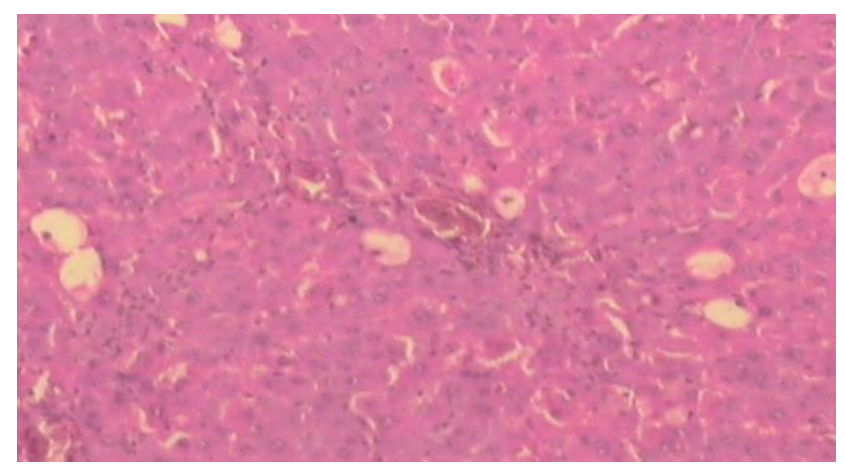

Figure 1c: Photomicrograph of liver from Group C showing features of regeneration and repair; $\mathrm{H} \& \mathrm{E}$ stain. View: $10 \mathrm{x}$ 40X.

\section{Additive effects of Mimosa pudica extract and Silymarin on concurrent administration}

Table 3 shows the comparison between Group D and Group $\mathrm{E}$ with Group $\mathrm{C}$ which shows that there is no significant difference between then three groups.

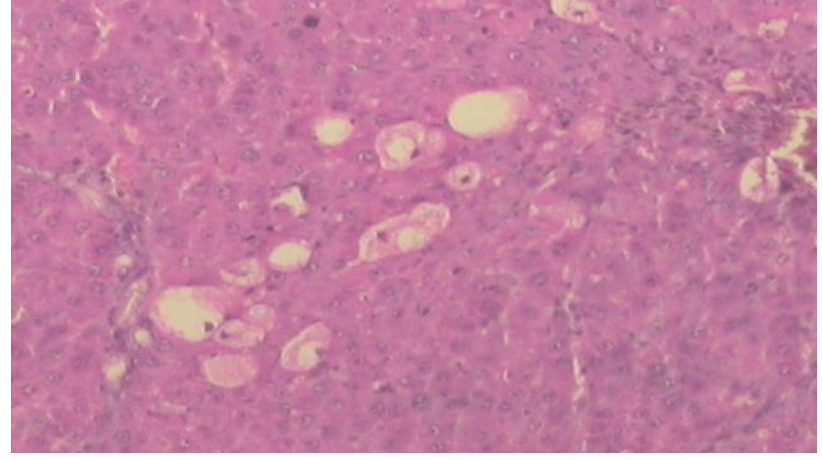

Figure 1d: Photomicrograph of liver from Group D showing features of regeneration repair; $\mathrm{H} \& \mathrm{E}$ stain. View: 10 x 40X.

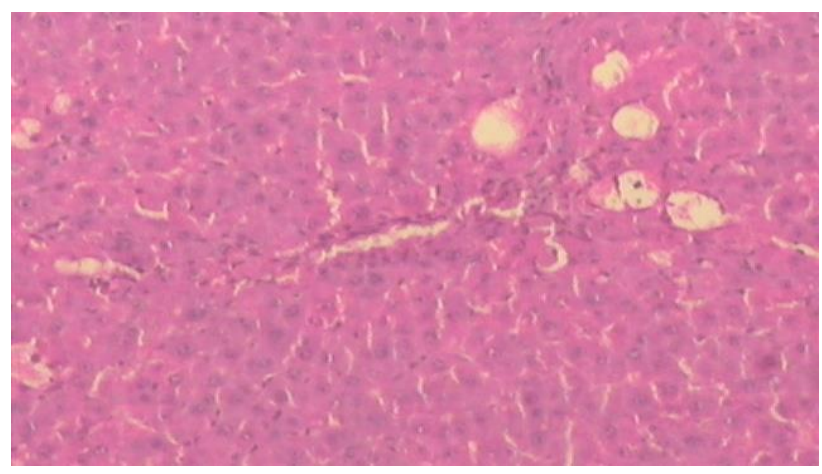

Figure 1e: Photomicrograph of liver from Group $\mathbf{E}$ showing features of regeneration and repair; $H \& E$ stain. View: $10 \times 40 X$.

\section{DISCUSSION}

In the living system liver is considered to be highly sensitive to toxic agents. The study of the liver enzyme activity has been found to be of great value in the assessment of clinical and experimental liver damage. ${ }^{20}$ Most of the hepatotoxic chemicals damage liver cells mainly by inducing lipidn peroxidation and other oxidative damages. Enhanced lipid peroxidation produced during the liver microsomal metabolism of ethanol may result in hepatitis and cirrhosis. ${ }^{21-22}$ Herbal medicine is based on the principle that plants contain some natural substances that can promote health and cure illness. ${ }^{6}$ The most important of these biologically active constituents of plants are alkaloids, flavonoids, tannins and phenolic compounds. Upon literature review it was found that Mimosa pudica possessed antioxidant properties and could very well serve as a hepatoprotective agent. The ethanolic extract of the leaves possesses different phytoconstituents like alkaloids, flavonoids, tannins, saponins, coumarin, terpenoids and phenlols. Flavonal aglycone and their glycosides are potent antioxidants which can prevent degenerative diseases and offer hepatoprotection. ${ }^{23}$ 
Table 3: Comparison between Groups C, D \& E.

\begin{tabular}{|c|c|c|c|c|c|}
\hline \multirow[b]{2}{*}{ Groups } & \multicolumn{5}{|c|}{ Biochemical parameters (Mean \pm SD) } \\
\hline & $\begin{array}{l}\text { Total Bilirubin } \\
(\mathrm{mg} / \mathrm{dl})\end{array}$ & $\begin{array}{l}\text { Direct Bilirubin } \\
(\mathrm{mg} / \mathrm{dl})\end{array}$ & AST (IU/L) & ALT (IU/L) & ALP (IU/L) \\
\hline $\begin{array}{l}\text { Group C } \\
\text { (standard) }\end{array}$ & $1.015 \pm 0.165$ & $0.66 \pm 0.103$ & $84.94 \pm 15.349$ & $74.78 \pm 19.181$ & $111.04 \pm 8.585$ \\
\hline $\begin{array}{l}\text { Group D (Test } \\
\text { drug) }\end{array}$ & $1.131 \pm 0.213 \mathrm{~ns}$ & $0.74 \pm 0.097 \mathrm{~ns}$ & $105.5 \pm 8.551 \mathrm{~ns}$ & $93.28 \pm 12.574 \mathrm{~ns}$ & $121.29 \pm 7.810 \mathrm{~ns}$ \\
\hline $\begin{array}{l}\text { Group E (Test } \\
\text { drug + standard) }\end{array}$ & $0.98 \pm 0.143 \mathrm{~ns}$ & $0.6 \pm 0.067 \mathrm{~ns}$ & $\begin{array}{l}90.237 \pm 11.423 \\
\mathrm{~ns}\end{array}$ & $79.267 \pm 7.169 \mathrm{~ns}$ & $\begin{array}{l}106.455 \pm 12.700 \\
\text { ns }\end{array}$ \\
\hline
\end{tabular}

Values are mean \pm SD $(n=6)$, data were analyzed using one way ANOVA. Where ns signifies non significant at $p>0.05$ (Comparison of treatment groups $\mathrm{D}$ and $\mathrm{E}$ with standard treatment group $\mathrm{C}$ ).

Carbon tetrachloride, a widely used experimental hepatotoxicant, is biotransformed by cytochrome $\mathrm{P}-450$ systems to produce the trichloromethyl free radical $(\mathrm{CCl} 3 \bullet)$ that causes lipid peroxidation and, thereby, produce liver damage. Carbon tetrachloride produces the dose dependent hepatotoxicity by directly affecting the liver, causing lipid peroxidation. ${ }^{24}$ Silymarin has been long used in the treatment for liver diseases as it restores liver enzyme activities due to its antioxidant properties, chelating metal ions, inhibiting lipid peroxidation, protecting the membrane permeability properties, and preventing liver glutathione depletion. ${ }^{25}$

In acute hepatic necrosis, increase in the serum level of glutamate pyruvate transaminase (GPT) is followed by an increase in the level of glutamate dehydrogenase (GDH), which is indicative of liver mitochondrial injury. ${ }^{26}$ This is evidenced by an elevation of the serum marker enzymes GOT, GPT, ALP and ACP in the carbon tetrachloride treated rats. $^{27,28}$

In the present study, treatment with ethanolic extract of Mimosa pudica $(400 \mathrm{mg} / \mathrm{kg}$ p. o.) significantly reversed these elevated marker enzymes, viz. - GOT, GPT, ALP and bilirubin (total and direct), and the results obtained were comparable with those of the Silymarin treated group. In our study, $400 \mathrm{mg} / \mathrm{kg}$ p. o. dose was highly effective against the hepatotoxicity caused by carbon tetrachloride. This was evident from biochemical parameters as well as macroscopic features i.e size of the lver. Also, in our study, a comparative histopathological study of the liver from different groups also shows the hepatoprotective efficacy of Mimosa pudica linn. However we could not find any significant additive effect when the two drugs i.e Silymarin and ethanolic extract of Mimosa pudica were given together. Further profound studies are required to establish the therapeutic potential of these two drugs when given together in case of acute liver injury.

\section{CONCLUSION}

In conclusion, our study demonstrates that the ethanolic extract of leaves of Mimosa pudica can be an effective treatment against liver injury.

\section{ACKNOWLEDGEMENTS}

We wish to thank our colleagues from the departments of Biochemistry and Pathology, Silchar Medical College and Hospital for cooperating with us and helping us to achieve what we desired to. We would like to thank M/s Segma Sales, Silchar, for providing us with all the materials within the desired time.

Funding: No funding sources Conflict of interest: None declared

Ethical approval: The study was approved by the Institutional Ethics Committee

\section{REFERENCES}

1. Ahsan MR, Islam KM, Bulbul IJ. Hepatoprotective activity of methanol extract of some medicinal plants against carbon tetrachloride-induced hepatotoxicity in rats. Eur J Sci Res. 2009:37(2):302-10.

2. Sharma A, Chakraborti KK, Handa SS. Antihepatotoxic activity of some Indian herbal formulations as compared to Silymarin. Fitoterapia. 1991:62:229-35.

3. Qadir MI, Ahmed B, Ali M, Saleem M, Ali M. Natural Hepatoprotectives: Alternative Medicines for Hepatitis. RGUHS J Pharm Sci. 2013:3(4):26-7.

4. Bodakhe SH, Ram A. Hepatoprotective properties of Bauhinia variegata bark extract. Yakugaku Zasshi. 2007:127:1503-7.

5. Bhawna S, Kumar SU. Hepatoprotective activity of some indigenous plants. Int J Pharm Tech Res. 2009:4:1330-4.

6. Joseph B, George J, Mohan J. Pharmacology and Traditional Uses of Mimosa pudica. IJPSDR. 2013:5(2):41-4. 
7. Nazeema TH, Brindha V. Antihepatotoxic and antioxidant defense potential of Mimosa pudica. International Journal of Drug Discovery. 2009:1(2):0975-4423.

8. Chauhan, Johnson BS, Davi E. Germination, emergence and dormancy of Mimosa pudica. Weed Biology and Management. 2009:9(1):38-45.

9. Kannan S, Aravinth VJS, Sam JKE, Saminathan J, Suthakaran R, Kumar R, et al. Wound healing activity of Mimosa pudica Linn formulation. IJPR. 2009:1(4):1554-58.

10. Chandrashekar DK, Manthale DM. Invention of analgesic and anti-inflammatory activity of ethanolic extract of Mimosa pudica Linn Leaves. Journal of Biomedical and Pharmaceutical Research. 2012:1(1):36-8.

11. Bum EN, Dawack DL, Schmutz M, Rakotonirina A, Rakotonirina SV, Portet C. Anticonvulsant activity of Mimosa pudica decoction. Fitoterapia. 2004:75(34):309-14.

12. Khalid S, Kumar JS, Suresh DK, Kumar R. Evaluation of anti-diarrhoeal potential of ethanolic extract of Mimosa pudica leaves. IJGP 2011:5(1):75-8.

13. Chowdhury SA, Islam J, Rahaman M, Rahman M, Rumzhum NN, Sultana R. Cytotoxic, antimicrobial and anti-oxidant activities of the different plant parts of Mimosa pudica. S J Pharm Sci. 2008:1(1\&2):804.

14. Rajendran R, Krishnakumar E. Hypolipidemic Activity of Chloroform Extract of Mimosa pudica leaves. Avicenna Journal of Medical Biotechnology. 2010:2(4):215-21.

15. Elango V, Carolin Oliver, Raghu PS. Antiulcer activity of the leaf ethanolic extract of Mimosa pudica in rats. Hygeia J D Med. 2012:4(1):34-40.

16. Gandhiraja N, Sriram S, Meena V, Srilakshmi K, Sasikumar C, Rajeshwari R. Phytochemical Screening and Antimicrobial activity of the Plant Extracts of Mimosa pudica L. against selected microbes. Ethnobotanical Leaflets. 2009:13:618-24.

17. Kaur P, Kumar N, Shivananda TN, Kaur G. Phytochemical Screening and Anti-Microbial activity of the plant extracts of Mimosa pudica Linn. against selected microbes. Journal of Medicinal Plants Research. 2011:5(22):5356-59.
18. Achliya GS, Kotagale NR, Wadodkar SG, Dorle K. Hepatoprotective activity of Panchegavya ghrita against carbon tetrachloride induced hepatotoxicity in rats. Indian J Pharmacol. 2003:35:308-11.

19. Galigher AE, Kayloff EN. Essentials of practical microtechniques. Philedelphia: Lee and Febiger: 1971.

20. Vaishwanar I, Kowale CN. Effect of two ayurvedic drugs Shilajeet and Eclinol on changes in liver and serum lipids produced by carbon tetrachloride. Ind J Exp Bil. 1976:14:58-61.

21. Ross and Wilson. Anatomy and Physiology in Health and Illness. 9th Edition. Elsevier Ltd. 2005:307-10.

22. Tortora GJ, Grabowski SR. Principle of Anatomy and Physiology.10th Edition. Hoboken, NJ: John Wiley \& Sons. 2003:875-9.

23. Roginsky V. Chain breaking antioxidant activity of natural polyphenols as determined during the chain oxidation of methyl linoleate in Trioton X-100 micelles. Arch Biochem Biophys. 2003:414(2):261.

24. Recknagal RO, Glenda EA, Dolak JA, Walter RL. Mechanism of carbon tetrachloride toxicity. Pharmacol Ther. 1989:43:139-54.

25. Banaee M, Sureda A, Mirvaghefi AR, Rafei GR. Effects of long term silymarin oral supplementation on the blood biochemical profile of rainbow trout (Oncorhynchus mykiss). Fish Physiol Biochem. 2011:37:885-96.

26. Zimmerman HJ. Hepatotoxicity. New York, US: Century Crofts. 1978.

27. Bhattacharyya D, Mukharjee R, Pandit S, Das N, Sur TK. Prevention of carbon tetrachloride induced hepatotoxicity in rats by Himoliv: A polyherbal formulation. Indian J Pharmacol. 2003:35:183-5.

28. Bhattacharyya D, Mukharjee R, Pandit S, Das N, Sur TK. Hepatoprotective effect of Himoliv: A polyherbal formulation in rats. Indian $\mathrm{J}$ Physiol Pharmacol. 2003:47:435-40.

Cite this article as: Purkayastha A, Chakravarty $\mathrm{P}$, Dewan B. Evaluation of hepatoprotective activity of the ethanolic extract of leaves of Mimosa pudica linn in carbon tetrachloride induced hepatic injury in albino rats. Int J Basic Clin Pharmacol 2016;5:496501. 